\title{
Rubber in East assures the perceived benefits; a case study showing increased rubber production, amelioration of the climate and improved rural livelihood
}

\author{
V H L Rodrigo*, S M M Iqbal*, E S Munasinghe*, B M D C Balasooriya* and \\ P M M Jayathilake* \\ * Rubber Research Institute of Sri Lanka, Dartonfield, Agalawatta, Sri Lanka
}

Received: 24 April 2014

\begin{abstract}
With the development of agronomic protocols to cultivate rubber in the prevailing conditions in the Eastern province and identification of land availability, the Ministry of Plantation Industries has launched an accelerated programme to establish 10,000 ha of rubber in this region. In addition to the increased rubber production, improved environment with forest cover and enhanced rural livelihood are expected. Proven evidence is required for the success of the programme; hence, as a case study, this was aimed to assess the potential of achieving the perceived benefits using firstly reached two rubber smallholdings to latex harvesting stage in Helakomana GN division. Latex yields to predict the potential rubber production in the region, changes in crop microclimate and evidence for changes in farmers' livelihood were evaluated. Basically, this programme has the potential of producing 15,000 MT of dry rubber annually with smallholder participation. A farmer having a hectare of mature rubber receives an average monthly income of about LKR 35,000. Income generated from rubber has empowered farmers to reap the benefits of recent infrastructure development in the region and to meet other family needs. Crop environment has been improved by rubber cultivation with $3.7^{\circ} \mathrm{C}$ reduction in air temperature and moderate level \%RH during the day time. This has provided better working conditions for farmers and would have an effect on regional climate once the targeted extent of rubber is grown. Rubber canopy has also protected the surface soil moisture.
\end{abstract}

Key words: climate, Eastern province, livelihood, rubber

\section{Introduction}

Rubber (Hevea brasiliensis Muell. Arg) cultivation in Sri Lanka began in large plantations; however at present, the biggest share in the extent is in the hands of smallholders. It represents $63 \%$ of the rubber extent producing ca.122, 000 MT of rubber annually 
(Anon, 2012a). The Government of Sri Lanka (GoSL) has identified the rubber industry as a thrust area and therefore, rubber cultivation and rubber based industries are promoted. At present, $c a$. $70 \%$ of the raw rubber produced is converted to value added products targeting mainly the export market. With no sufficient lands for further cultivation of rubber in traditional growing areas of the country, i.e. Wet Zone (WZ), the Ministry of Plantation Industries has decided to expand rubber to drier areas. Southern and Uva provinces were initially targeted for rubber cultivation and then with the end of terrorism, the priority has been given to the Northern and Eastern provinces. Agronomic protocols for successful rubber cultivation have been developed (Anon, 2012b) and thereafter, farmers are motivated and attracted to cultivate rubber. In addition to the rubber production, GoSL seeks multiple benefits in this expansion process. In particular, improved environment with forest cover and enhanced rural livelihood are directly focused. Initial estimates based on a sample study showed that over 10,000 ha of lands are available to cultivate rubber in the Eastern province of Sri Lanka (Rodrigo et al., 2010). Further, land availability and farmers' willingness to cultivate rubber were found to the biggest strengths whilst lack of knowledge on rubber, problems associated with proving the land ownership to claim subsidy payments given by GoSL for rubber and lack of financial assets at farmer level were the principal weaknesses for promoting rubber cultivation in the region (Rodrigo et al., 2010). Moreover, traditional farming systems in the peasant community were found to be for rather daily subsistence with only about LKR 60,000 circulating in a family per year (Rodrigo et al., 2009). Therefore, in providing the rubber planting subsidy which provides LKR 150,000 per hectare in eight installments spread out in the initial gestation period (Anon, 2013), high priority has been given to the nontraditional areas such as Eastern and Northern provinces. Also, an additional payment to prepare planting holes before the rainy season (LKR 60 per hole) has also been given to assure the planting on time.

Previous finding on the availability of lands over 10,000 ha in Ampara district has been confirmed by the Land Use Division of District Secretariat. Seeing the success in the introduction phase of rubber cultivation, the Ministry of Plantation Industries has launched an ambitious programme to cultivate 10,000 ha within three years. By the end of 2013, 688 ha have been cultivated with 1219 farmers. Despite the intervention made by the government, the success of the programme depends on the ability to prove the perceived benefits of rubber cultivation in this region. Therefore, the present study was aimed to assess the potential of receiving the perceived benefits through the on-site observations. 


\section{Material and Methods}

With three main perceived benefits, the study was conducted in three directions, i.e. assessing latex yields to predict the potential rubber production in the region, changes in crop microclimate and evidence for changes in farmers' livelihood. Since rubber was firstly planted and then tapped in HelaKomana GN division, the study area was confined to the same.

The days rubber trees were tapped and latex yields on each day in terms of number of rubber sheets produced were available in two sites for a certain period; hence the same was collected (from April 2011 to March 2012) to assess the yields together with the information on average weight per sheet and number of trees being tapped. Considering the number of trees available and the land extent in each site, yield per tree and per hectare was estimated. Seasonal changes in rubber yields were also assessed.

In order to assess the changes in crop microclimate, an area of the village where mature rubber fields were extensively available was selected. Diurnal measurements starting from $0600 \mathrm{~h}$ to $1800 \mathrm{~h}$ on air and soil temperatures, \%RH and soil moisture were taken inside the mature rubber fields and outside where cash crops (i.e. maize) were grown. Pocket Weather Station (Kestrel $4000 \mathrm{NV}$ ) was used for temperature and \%RH measurements. Soil temperature and moisture were measured in the surface soil up to the depth of $7 \mathrm{~cm}$ using Soil Moisture
Sensor (SMEC 300, Spectrum Technologies, Inc.).

Assessments on the changes in rural livelihood were basically confined to two farmers used for yield assessments since they possessed the information on rubber sales. These were the ones who continued to have rubber till latex harvesting after the initial planting in Eastern province in 2003. Although others who planted rubber in subsequent years started latex harvesting later, no proper records on rubber sales were available. Income from rubber was counted and farmers were questioned for other incomes and at the stages of before and after the income generation from rubber. Crop distribution pattern was studied before and after the introduction of rubber. Further, information on key changes in farmers' expenditure associated with the income generated from rubber was obtained. Evidence for changes in expenditure was also collected for reconciliation. Data analyses were rather descriptive and illustrative methods were used to elaborate findings.

\section{Results and Discussion}

On average, $946 \mathrm{~kg}$ of rubber was produced annually in a land extent of one hectare during early stages of latex harvesting. The highest yield per tree per tapping day was recorded in the month of April (Fig.1a) and number of days tapped was also highest in the same month (15) resulting in the highest yield. Similarly, months of August, September and March have given higher yields than the rest (Fig.1b). Traditional 
new-year falls in April during which farmers usually spend more time for cultural activities than on farming. New experience in latex harvesting would have motivated farmers to do tapping in this month in initial stage; however it may not be the case in every year. Frequent rains caused low yields from October to December and virtually no tapping in December. Dry weather has also resulted in low yields in July forcing farmers to stop tapping. Only 8 days of tapping were recorded in July. Rubber trees are expected to tap once in two days; hence, potential tapping days per year per tree is 182 (i.e. 365/2). However, total number of days a tree had been tapped per year was recorded as 129 . Because of the rain interference, farmers were unable to tap for 27 days

a.

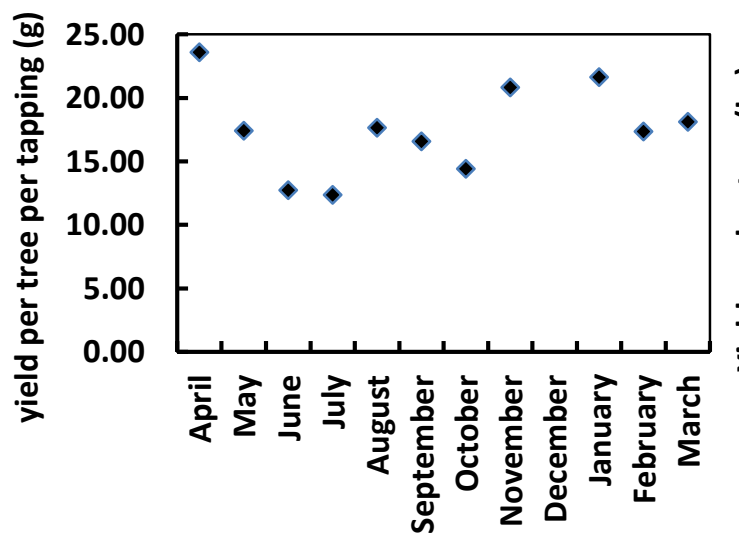

whilst dry weather caused 7 no tapping days. No details on the distribution of number of tapping days in the smallholder sector in the traditional wet zone are available; however, a tree has been tapped on average for 119 days (Anon, 2010). In this context, farmers in Eastern province were able to tap additional 10 days compared to the smallholders in the wet zone. In the estate sector of traditional wet zone, 147 tapping days per tree have been recorded mostly with rainguards (Munasinghe, 2009). Although rain interference caused reasonable number of no tapping days, success of rainguard application in this region is dubious as heavy rains during monsoons make farmers difficult to reach trees during November-December time.

b.

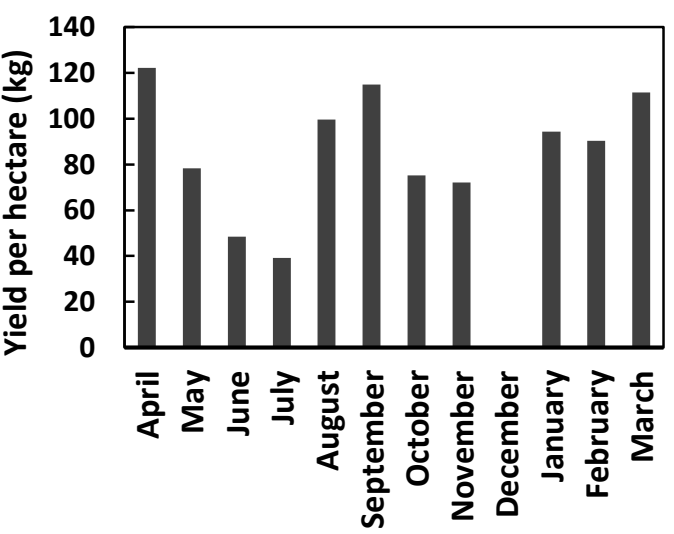

Fig. 1. Monthly variation in rubber yield, (a) per tree per tapping (g) and (b) per hectare (kg) throughout the year 
Average yield per tree per tapping under $\mathrm{d} / 2$ frequency was recorded as 18 grams in the Eastern province and was comparable with the values recorded in the wet zone during the first year of tapping (Anon, 2009). Yields are expected to increase in subsequent years with tree growth (Anon, 2009); hence on average $1500 \mathrm{~kg}$ per hectare per annum are likely at full maturity. On this basis, 10,000 ha may eventually produce $15,000 \mathrm{MT}$ of rubber annually in the Eastern province.

Effect of rubber trees in reducing air and soil temperature was evident during the day time from $0800 \mathrm{~h}$ to $1600 \mathrm{~h}$ (Fig. 2 \& 3). Air temperature difference between seasonal and rubber crop lands was greater between $0900 \mathrm{~h}$ to $1200 \mathrm{~h}$ with the highest difference recorded as $6.4{ }^{\circ} \mathrm{C}$ at $1100 \mathrm{~h}$. Average for the period from $0800 \mathrm{~h}$ to $1600 \mathrm{~h}$, mature rubber plants reduce the air temperature by $3.7^{\circ} \mathrm{C}$ over the value at seasonal crop lands. In the working environment of seasonal crop lands, farmers have to experience very high temperatures, i.e. $36{ }^{\circ} \mathrm{C}$; hence $3.7^{\circ} \mathrm{C}$ decline in rubber fields means high level of comfort in the working environment. Reduction in soil temperature was similar to the air temperature with an average decline of $2.6^{\circ} \mathrm{C}$ recorded in rubber soils. Air temperature reached the peak at $1200 \mathrm{~h}$ in seasonal crop area and at $1300 \mathrm{~h}$ in rubber crop showing a buffering action of rubber trees to control the air temperature.

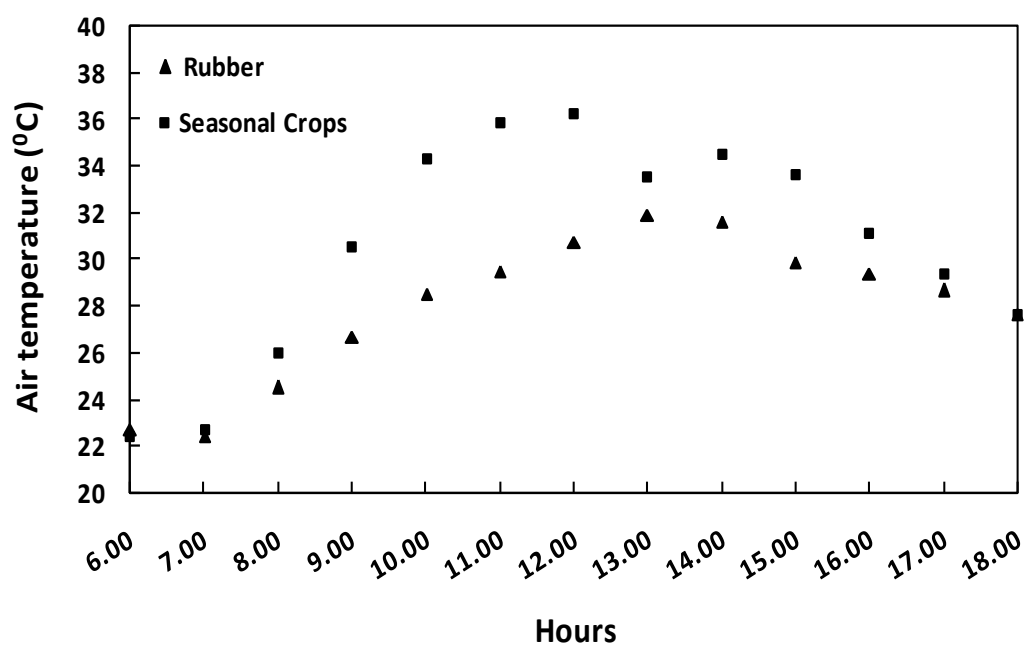

Fig. 2. Diurnal variation in air temperature in rubber and seasonal crop fields 


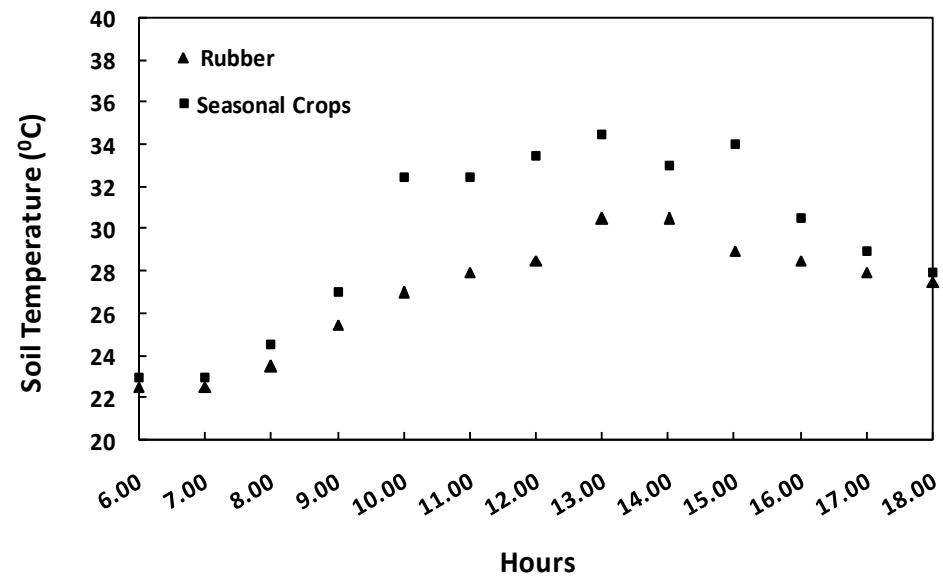

Fig. 3. Diurnal variation in soil temperature in rubber and seasonal crops fields

Values recorded for relative humidity (\%RH) was higher in rubber fields with ca. $11.4 \%$ difference from seasonal crop lands, particularly from $0900 \mathrm{~h}$ to 1500 $\mathrm{h}$ (Fig. 4). The highest \%RH in either field was recorded at $0700 \mathrm{~h}$ with values over $85 \%$. \%RH dropped up to $45 \%$ in seasonal crop field by mid-day time; however, it never dropped below 52\% in rubber fields. Moderate \% $\mathrm{RH}$ and comparatively low temperature provide comfortable environment for people to live in. With the expansion of rubber cultivation in the region, such situation will exist in a large extent of land and would have an impact on the regional climate. This view is supported by the observations made elsewhere (Jiquan Chen et al., 1999).

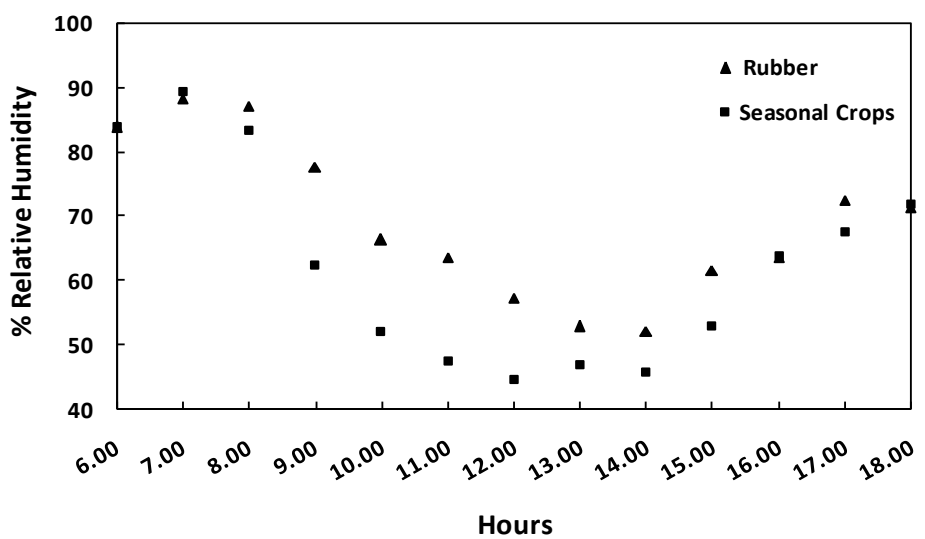

Fig. 4. Diurnal variation in relative humidity in rubber and seasonal crops fields 


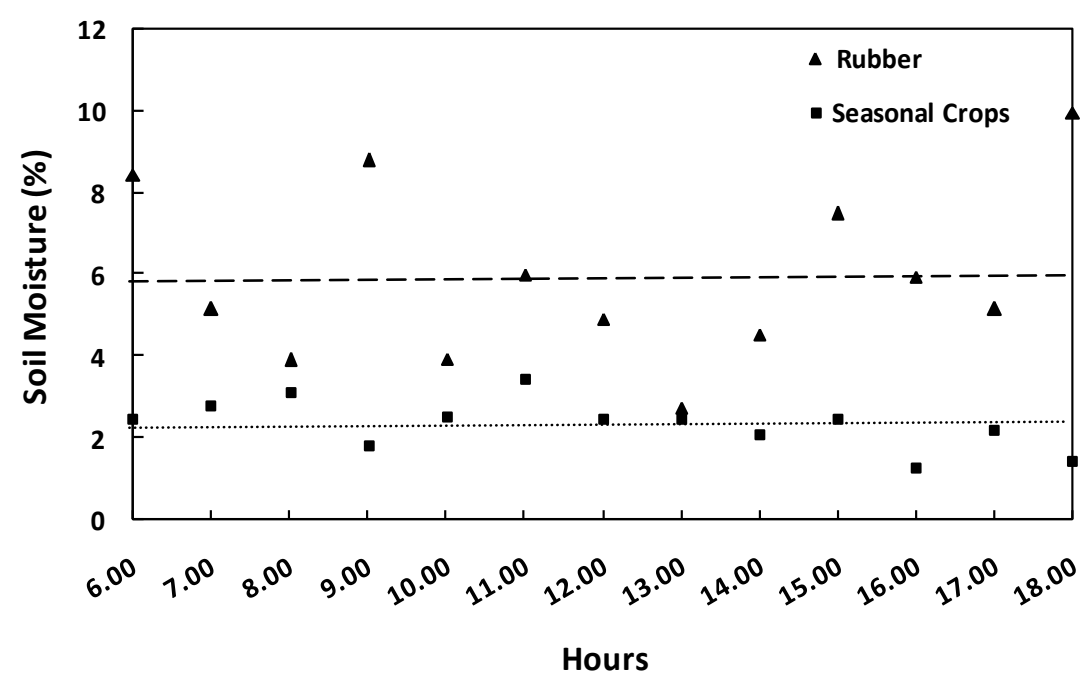

Fig. 5. Diurnal variation in soil moisture in rubber and seasonal crop lands. Mean values for rubber $(5.9 \%)$ and seasonal crops $(2.3 \%)$ are shown as [----- ] and [.... ], respectively

Having taken the measurements in dry period and only up to $7 \mathrm{~cm}$ depth, values recorded for surface soil moisture were in rather low side and also, no clear diurnal variation was noted in either type of field (Fig. 5). However on average, rubber soil has reported a value of $5.9 \%$ volumetric moisture content which was over $100 \%$ higher than the values of seasonal crop fields. Tree canopy given by rubber creates high level of boundary layer resistance restricting water evaporation. This would have been the cause for high level of soil moisture in rubber soils and further evident from high \% RH values recorded.

Having mature rubber in 0.7 ha and produced $709 \mathrm{~kg}$ of rubber, Farmer 1 received LKR 347,410 per year whilst $528 \mathrm{~kg}$ of rubber from 0.6 ha provided LKR 258,720 to Farmer 2. Since farmers use family labour for all activities of rubber cultivation, cost of production was virtually negligible with LKR 10.50 spent per one kilogram of rubber (N.B. This is basically for chemicals). Previous income received (before harvesting rubber) by Farmer 1 and 2 was LKR 200,000 and LKR 180,000 respectively. In addition to rubber, they received LKR 157,000 and LKR 153,000 from other activities; hence the income increase was as high as LKR 304,410 (152\%) and LKR 231,720 (129\%), respectively. Such gains in income have improved farmers' purchasing power in different dimensions. Infrastructure development provided by the government such as provision of electricity and tarmac roads drives farmers to enjoy various other benefits. A variety of electrical home appliances were purchased by both farmers and farmer 2 has purchased a three-wheeler on lease basis. Both 
farmers have done primary level of renovation to their houses and obtained electricity, water supply. Further, additional financial support has been given for the education of children of Farmer 2 (N.B. All children of Farmer 1 were married).

Although seasonal crops are still grown by both farmers, their extent has diminished. In both farmers, seasonal crop cultivation as a mono crop is limited to 0.2 ha from the earlier 1.22 ha (Table 1a \& b). Apart from that, both farmers cultivate seasonal crops in immature rubber lands as intercrop.
Knowing the income given by rubber, farmers intended to cultivate rubber in all possible lands. According to the crop distribution, rubber has not influenced the cultivation pattern and extent of their subsidiary crops (e.g. paddy, cashew and coconut). Also, leisure time activities of both farmers have been increased. Farmer 1 spend more time than in past on village level societies and visiting his married children who live elsewhere. Farmer 2 spends more time on village level societies and other social activities in the village.

Table 1a. Distribution of crops before and after introducing rubber-Farmer 1

\begin{tabular}{|c|c|c|c|c|c|}
\hline \multirow[t]{2}{*}{ Crop } & \multicolumn{2}{|c|}{$\begin{array}{c}\text { Before introducing } \\
\text { rubber }\end{array}$} & \multicolumn{2}{|c|}{$\begin{array}{c}\text { After introducing } \\
\text { rubber }\end{array}$} & \multirow[t]{2}{*}{ Remarks } \\
\hline & Area (ha) & $\begin{array}{r}\text { Income } \\
\text { (LKR) }\end{array}$ & Area (ha) & $\begin{array}{r}\text { Income } \\
\text { (LKR) }\end{array}$ & \\
\hline Paddy & $0.20 *$ & - & $0.20 *$ & - & \\
\hline Cashew & 1.22 & 75,000 & 1.22 & 50,000 & $\begin{array}{l}\text { Low income due to } \\
\text { disease condition }\end{array}$ \\
\hline Lime & 0.82 & 50,000 & - & - & Fire damage \\
\hline Coconut & $0.20 *$ & - & $0.20 *$ & - & \\
\hline Mango & 0.41 & - & 0.41 & 5,000 & \\
\hline $\begin{array}{l}\text { Seasonal crops as mono } \\
\text { crop }\end{array}$ & 1.22 & 75,000 & 0.20 & 42,000 & \\
\hline $\begin{array}{l}\text { Seasonal crops as } \\
\text { intercrop with immature } \\
\text { rubber }\end{array}$ & - & - & 2 & 60,000 & \\
\hline Mature rubber & - & - & 0.70 & 347,410 & \\
\hline
\end{tabular}

* Used only for subsistence 
V H L Rodrigo et al.

Table 1b. Distribution of crops before and after introducing rubber-Farmer2

\begin{tabular}{llclc}
\hline Crop & \multicolumn{3}{l}{ Before introducing rubber } & \multicolumn{2}{l}{ After introducing rubber } & Remarks \\
\cline { 2 - 4 } & $\begin{array}{l}\text { Area } \\
\text { (ha) }\end{array}$ & $\begin{array}{c}\text { Income/ha } \\
\text { (LKR) }\end{array}$ & $\begin{array}{l}\text { Area } \\
\text { (ha) }\end{array}$ & $\begin{array}{c}\text { Income/ha } \\
\text { (LKR) }\end{array}$ \\
\hline Paddy & $0.41^{*}$ & & $0.41^{*}$ & \\
Cashew & 1.63 & 100,000 & 1.63 & 100,000 \\
Lime & 0.82 & 50,000 & 0.20 & 15,000 \\
Coconut & $0.61^{*}$ & & $0.61^{*}$ & \\
Seasonal crops as & 1.22 & 30,000 & 0.20 & 38,000 \\
mono crop & & - & 1.00 & 30,000 \\
Seasonal crops as & - & - & & \\
intercrop with & & & & \\
immature rubber & & - & 0.60 & 258,720 \\
Mature rubber & - & & & \\
\hline
\end{tabular}

* Used only for subsistence

\section{Conclusions}

Rubber grown with the smallholder farmers in the Eastern province has been able to provide a reasonable yield offering substantial income to the farmers. Yields were comparable with that in traditional wet zone; however both heavy rains during monsoon period and dry spells in July disabled rubber tapping.

On completion of the target of planting rubber in 10,000 ha, there is a potential to produce $15,000 \mathrm{MT}$ of rubber annually from the region. At farmer level, rubber cultivation has increased the income by well over $100 \%$ and thereby the purchasing power. Improved rural livelihood was evident with the renovation of houses, purchase of home appliance and investment on education. Rubber cultivation has also resulted in improvement in working environment by reducing day time air temperature on average by $3.7{ }^{\circ} \mathrm{C}$ and maintaining moderate level of $\% \mathrm{RH}$.

Although this case study provides evidence for receiving threefold benefit of rubber cultivation, i.e. increased rubber production, enhanced rural livelihood and improved environment, further studies are required to ascertain those benefits in more comprehensive manner.

\section{References}

Anon (2009). Yield profiles of outstanding clones. Advisory Circular, Genetics and Plant Breeding Department, Rubber Research Institute of Sri Lanka.

Anon (2010). Review of the Adaptive Research Unit. Annual Review of Rubber Research Institute of Sri Lanka. Pp. 176 - 190 .

Anon (2012a). Statistical Information on Plantation Crops. Ministry of Plantation Industries, Colombo, Sri Lanka. 
Anon (2012b). Planting and immature upkeep of rubber, Eastern province. Leaflet, Adaptive Research Unit, Rubber Research Institute of Sri Lanka.

Anon (2013). Subsidy Scheme for Rubber Replanting and New Planting. Circular No. 2011/05, Rubber Development Department, Ministry of Plantation Industries, Sri Lanka.

Jiquan, Chen, Sari C Saunders, Thomas, R Crow, Robert, J Naiman, Kimberley, D Brosofske, Glenn, D, Mroz, Brian, L Brookshire and Jerry F Franklin (1999). Microclimate in forest ecosystem and landscape ecology. Bio Science 49 (4), 288-297.

Munasinghe, E S (2009). Growth, yield, carbon fixation and economics of rubber cultivation in Sri Lanka. PhD Thesis, University of Sri Jayewardenepura, Sri Lanka.
Rodrigo, $\mathrm{V} \mathrm{H}$ L, Iqbal, S M M and Munasinghe, E S (2009). Rural livelihood and rubber cultivation in Eastern province of Sri Lanka. Journal of the Rubber Research Institute of Sri Lanka 89, 58-69.

Rodrigo, V H L, Iqbal, S M M and Dharmakeerthi, R S (2010). Potential for the expansion of rubber (Hevea brasiliensis Muell. Arg.) Cultivation to Eastern province of Sri Lanka. Journal of the National Science Foundation of Sri Lanka 39 (4), 403-411.

Address for correspondence: Dr V H L Rodrigo, Additional Director, Rubber Research Institute of Sri Lanka, Dartonfield, Agalawatta, Sri Lanka.

e-mail:laksh@sltnet.lk 